\title{
Atamira Dance Company and Indigenous Performance: The Making of Māori Worlds
}

Mutton bird rituals, harvesting kelp, bush clad hillsides, and the majestic moon illuminating the southern Pacific ocean at Kaka point/Catlins is danced by Aotearoa/ New Zealand's stand out Atamira Dance Company based in Auckland. Their dancing is accompanied by the mesmerizing soundscape composed by Richard Nunns and Paddy Free, who provide rich audio textures that combine electronica beats with stone percussion and gourd instruments. The work is entitled Taonga: Dust, Water, Wind and premiered in 2009 at the Sky City Theatre in Auckland as part of the Auckland Arts Festival. Louise Potiki Bryant, the distinguished (Kai Tahu) choreographer made the work to ruminate about her great Aunt Rona Williamson, who was born in 1924. The dance was about her experiences of growing up by the sea during the Great Depression, the piece uncovers what could have remained buried family stories. In a radio interview, Potiki Bryant said, "I wanted to honor how special she is" (2009). Revealed was a picture of Potiki Bryant's elders, her antecedents and the intimate relationship they had with the land they lived, Kaka point.

The shadowy stage blended video images of rock, water, sky and people; the dancers and images evolve and dissolve. A reviewer of the show, Rae (2009) says the use of film is 
signature to Potiki-Bryant's multimedia style along with her gorgeously effective stage design such as-"burnished copper vessels, a mythological significant tree and three suspended shapes suggesting the kelp bags used for preserving mutton birds and against which moving images of water are reflected". Rae calls this "highly evocative". The performance immersed you into the many dimensions of what life was like when Rona was a girl. The show featured a range of her memories, from doing the washing, to harvesting and preparing kai/food, the weather, the ocean tides, wind direction, the phases of the moon, Rona's conversations and experiences with her Mum, the joys and traumas of the family to her playful imaginings and fascination with birds. 


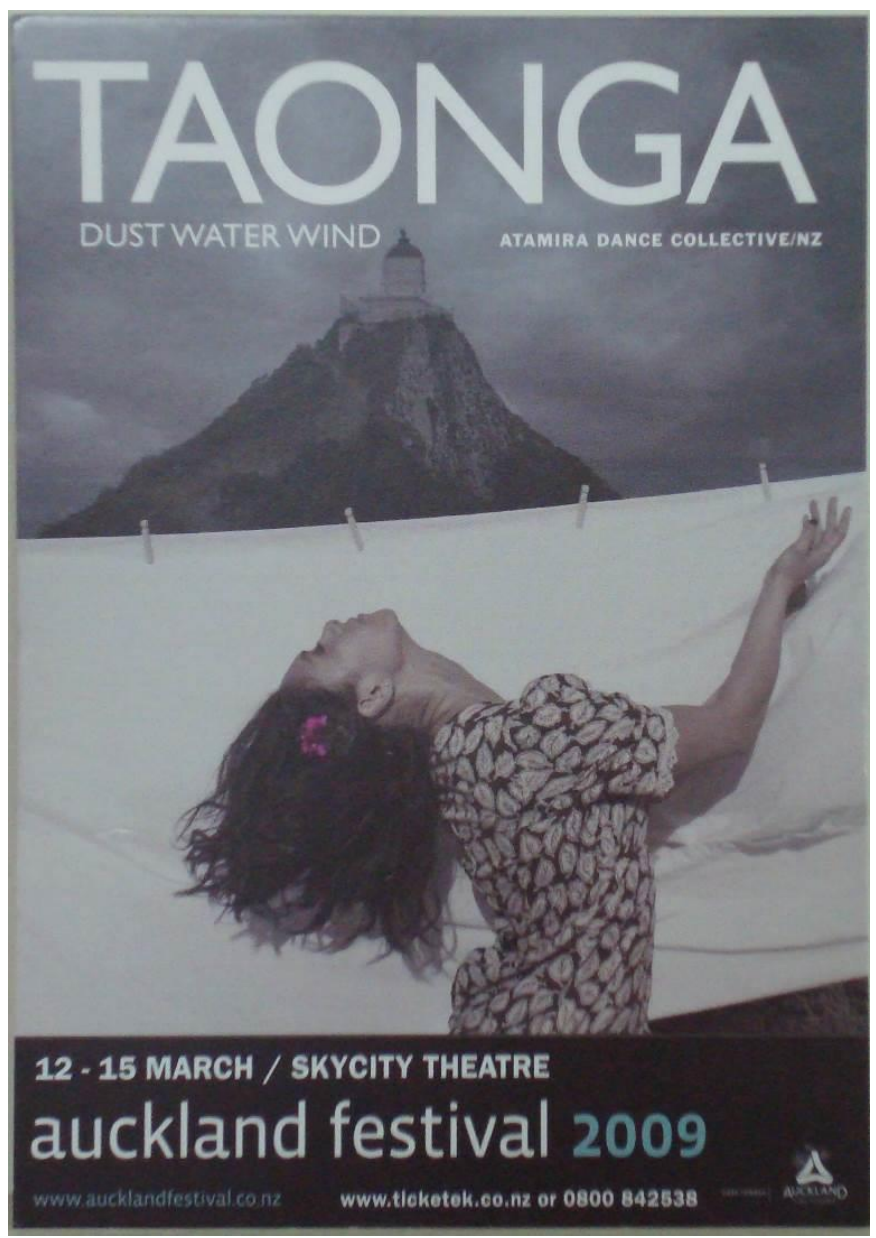

Photo: Ojeya Cruz Banks

Pictured: Atamira Dance Company Taonga Poster

The above description of the Atamira Dance Company, a Māori Contemporary Dance Theater, examples a Pacific island epistemology articulated by Hau'ofa (2000) who wrote, "Our landscapes and seascapes are thus cultural as well as 
physical. We cannot read our histories without knowing how to read our landscapes [and seascapes]". The company's performance demonstrates landscape to be an active character in the development of indigenous knowledge and performance. The paper investigates how Atamira's work invigorates distinctive indigenous Māori ecological ideologies and practices that yield heritage, creativity and worlds through dance. The portrait of Taonga shows the company cultivating biophila or environmental bonding (Orr, 1994); the relevancy of this concept is explained later in this paper.

\section{The Company and Indigenous Dance Aotearoa in Context}

Aotearoa/New Zealand is fertile ground for moving indigenous Pacifica dance forward. People such as Stephen Bradshaw, Charles Koroneho, Moana Nepia, Okareka Dance Company and others have been mentors and inspiration for the Atamira Dance Company. The first Māori "contemporary" dance company, Taiao Dance Theatre (previously known as Te Kanikani o te Rangatahi) was founded in 1984 by a collective of artists that included Bradshaw, who was former member of the Limbs Dance Company. I put quotations around the word contemporary because the description is contested. Bradshaw (2015) and Gray (2015) agree it is an inappropriate term because it is a Pākeha/ western cultural construct. Koroneho (2014) says he prefers 'indigenous performance or haka' (Marae T.V program). However, Bradshaw (2015) acknowledges the term contemporary has currency; it is comprehensible to funders and audiences. He and the other members of Taiao used the phrase continuum Māori dance as they wanted to use their performances "to acknowledge our whakapapa or ancestral past within a changing world (Bradshaw 2015, p. 80). Today there are a significant number of solo Māori dance artists such as Tru Paraha, Tanemahuta Gray, Cat Ruka, Kura Te Ua to name a few, who are developing their unique styles, and ideas. Kōwhiti Dance 
Festival and Awards was spearheaded in 2010 by brother and sister team Merenia and Tanemahuta Gray along with Jenny Stevenson. The event showcases Māori and other indigenous artists, and in 2013 the symposium Atarau Symposium: Illuminating Indigenous Terrains of Intercultural Dance held in November 2013 in Wellington was added to the bill. I presented an early draft of this paper there. In 2011 Atamira hosted in Auckland an International Indigenous Choreographic Laboratory in collaboration with Marrugeku, an organization based in Sydney, Australia that leads indigenous choreography workshops to explore creative challenges facing contemporary Indigenous dance. The goal of the lab was to dialogue and experiment in movement research. Furthermore, there are internationally celebrated Pasifika choreographers born in New Zealand but of Samoan descent such as Neil Ieremia (Black Grace) and Lemi Ponifaso (MAU) who create work grounded in their heritage, diaspora, intercultural experiences and dance training. The country is a center for inventive indigenous dance working through postcolonial and migration predicaments while asserting Oceania epistemic sovereignty and cultural innovation.

Atamira Dance Company is considered a major player in the 'coming of age' of contemporary Māori dance (Bradshaw 2015, 89; see also Sciacsia 2013, Zaitz 2009). A paniwi/tribal collective of artists, their movement vocabulary includes Māori archetypes and elements, ballet, and contemporary techniques coupled with influences from sport, hip hop and yoga. They have regular national tours and perform across the Pacific, Asia and the United States; they are reputed for their cutting edge approaches to performance and for their commitment to telling important Māori stories. Atamira's work has been performed at the traveling Pacific Arts Festival that includes over 2000 Oceania artists and to the internationally acclaimed summer dance festival known as Jacob's Pillow. Their work "uplifts, discovers and facilitates" (Bradshaw, 2015, p.89) and innovates Te Ao Maori worlds. 


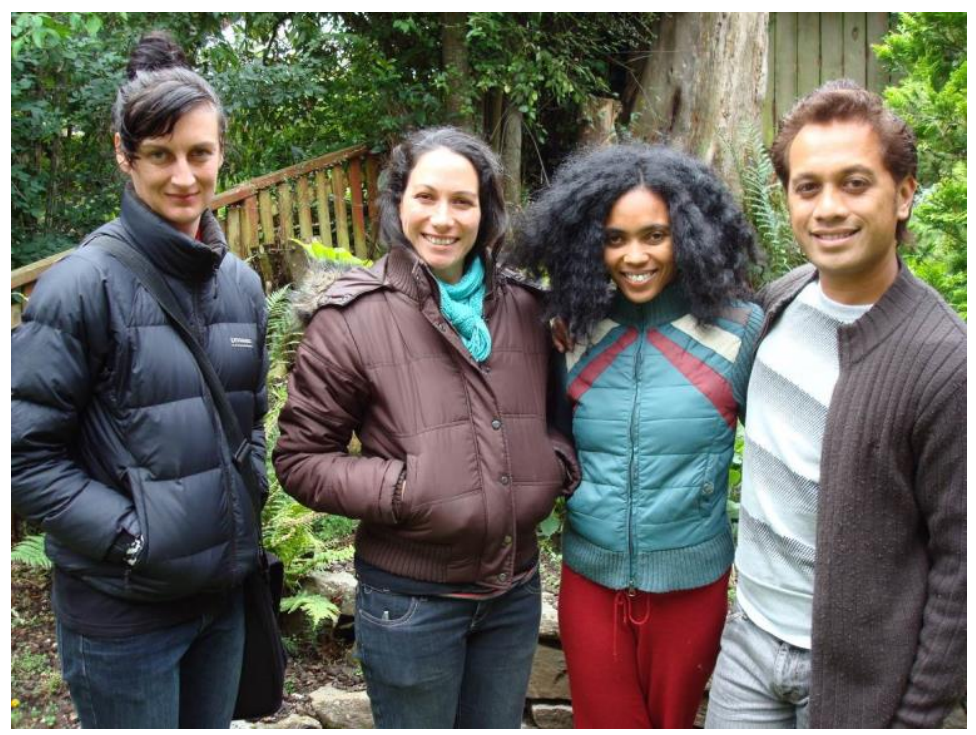

Photo: Ojeya Cruz Banks

Pictured L to R: Louise Potiki Bryant, Dolina Wehipeihana, Ojeya Cruz Banks, Jack Gray: Dunedin April 2009

I was deeply moved by the work of Atamira Dance Company in 2008 when I relocated to Aotearoa/New Zealand for work, from the United States. As a Pacific Islander (Guåhan)/African American, the research immersed me into new dance perspectives that were unique to Aotearoa; the company inspired me to reconnect to my Pacific homeland and take notice of cultural revitalization challenges facing many Pacific Island people (Cruz Banks, 2013). For this research, I have used the methodology- dance ethnography, an approach concerned with the process of dancing, reading dance, listening to the voices of dancers and recalling dance description. The late legendary African- American choreographer and anthropologist Katherine Dunham (1947; 2005) foregrounded dance ethnography and argued that 
understanding how a given community perceives their dance is of the utmost importance; reading dance holistically, as Dunham suggests is more important than understanding a particular movement action or a specific performance (1947; 2005). Kaeppler $(1978,2000)$ adds that this approach pays close attention to cultural intention, meaning, movement content and the wider socio-political context.

My study of the Atamira Dance Company was carried out between October 2008-2012; however this particular paper focuses on the period of 2008-2010. I should add that many founding members are no longer active in the company; the ensemble has evolved significantly. For instance, there is almost an entire new cast of dancers, and I am noticing a different tone developing in the company. However these changes are not discussed within the scope of this paper.

The research seeks to understand how Atamira's work invigorates distinctive indigenous Māori ecological ideologies and practices that yield heritage, creativity and worlds through dance. Information is gleaned through participationobservation and analysis of the following: Atamira's productions, spending time with the company, dancing with them, reading their performance programs and reviews, and informal conversations with the company dancers about their work. Moreover, field notes were logged and video recordings, photography and archival research was also carried out.

\section{Biophilia Meet Kaitiakitanga: Māori Dance Ecologies}

Renowned ecologist David Orr (2004) argues we are in an age of environmental terrorism, a time of violent and disastrous consequences on the natural world and human beings, caused by profit- minded economic and military decisions. His observations and research in the United States call for deeper awareness and emotional relationships to environments. We need to overcome he says a narrow view of things. Simply put, he says we need to be more cognizant of Wilson's (in Orr, 
1994) term biophilia which describes how people subconsciously and consciously seek and require connections with the rest of life. He says our societies desperately need robust values that enhance our ecological empathy and ethics. What is missing from Orr's discussion of biophila is an indigenous perspective of ecological consciousness likened to biophilia. I add a viewpoint of human-land relations based on Māori ontologies and cosmologies, as practiced by the Atamira Dance Company. Their performance research is often about synthesizing a land and identity equation that asserts a Te Ao Māori worldview.

An important mentor and research collaborator for the company, Te Ahukaramū Charles Royal, articulates an ethics of Māori performing arts that is tied to whenua/ land. Royal (2007; 2009b; 2010) discusses efforts toward creating a new indigenous theater and one that examines the stories of pre European contact dance to galvanize new possibilities of Māori creativity. He has revived the whare tapere/ house of entertainment that fell out of use in the 19th century due to colonialism and Christian ideologies. The whare tapere is important to the genesis of Māori dance; within this institution he proposes "the natural world should find expression through human creativity and performance in Aotearoa" (2007, p. 204). Royal says in traditional Māori culture the relationship with nature is ritualized and environmental elements are used as models of dance. Members of the company have contributed to Royal's research, especially Potiki Bryant, who has worked closely with him and developed the research with her own tribe. Whare tapere research is fueled by the ancient Māori mythological archetypes such as Hineruhi and Tanerore, whose elements of water, light, sky and heat are inspirations for Māori dance creativity (Royal, 2009b, 2010).

Royal's uncle and mentor, Marsden (1992) explains that the sons and daughters of Aotearoa have a spiritual obligation to be guardians of the whenua/land. He explains whenua is not perceived as commodity but a gift from the gods inscribed 
with cosmology. The ethos of Kaitiakitanga or the process of stewardship to mother earth is about protection and sustainability of land and sea. The philosophy provides jurisdiction of environmental law and the protection of food resources and exploitation (Gray 2015; Kawharu 2000; Smith 2011; Moko Mead 1992).

Learning to be a guardian and caretaker of the environment and people is the principle of Kaitiakitanga, and this is comparable to Wilson and Orr's notion of biophila or ecological empathy. From a Māori perspective Kaitiakitanga generates identification with earth and an embracing of genealogy or whakapapa. Smith (2011) says whakapapa is about identity and interconnectedness or in other words it is about where you come from and where you belong. Whakapapa is about centering yourself with the land that nourishes you and your family for generations. The land and sea are sacred places where the bones of ancestors rest. The whakapapa worldview nourishes responsiveness to being kaitiaki. It is designed to keep one conscious and active in understanding the evolution and relationship between all things (Smith 2011).

\section{Mana Whenua: Land Rights and Dance}

The legacy of Māori land march of 1975 was described as "an awakening of the people" (Smith, 2011, p. 122). The founding members of the Atamira Dance Company are the mokopuna/grandchildren of this political activism. The hikoi/march was under the direction of the coalition/ Te Roopu Matakite, and traveled 1126 kilometers toward the final destination of Parliament in Wellington. They delivered a petition that was signed by 200 pan-iwi/tribal leaders to the Prime Minister demanding control and retention of Māori land. Over 5000 people joined forces to address land loss issues and the reassertion of their sense of belonging to ancestral land. Land is a source of spiritual strength and well-being (Royal 
2009a; Smith 2011). The Atamira Dance Company's work demonstrates the significance of this cultural-environmental consciousness; and their work often involves the continued assertion of the integral human-land relationship. For instance, when Potiki Bryant was interviewed about Taonga and her relationship to land, she replied "there is no separation. It does give me an identity and a sense of belonging, however it also keeps me humble. I am not separate from anything (2009, Big Idea). A few years later, founder of the company Gray (2015) discusses the importance of 'being kaitiaki'/guardians of the land as a cultural ideal. He says Māori people do not have authority over the land but rather with it; this is mana whenua or land empowerment (Gray 2015; Royal 2009; Smith 2011). Gray (2014) has also said when people do not know this, one's identity is fractured. Land loss or not experiencing interconnectedness to land is a psychologically destructive and has grave environmental consequences as Orr (1992) passionately discusses. To desecrate and commodify land is an injury to the health of Māori people. The Atamira Dance company affirms and recovers mana whenua by collecting ancestral stories that educate them about their family stories that live in the contours of the land.

For example, Mazer (2007) describes the Atamira Dance Company, and their award winning performance 'Nga Tahu 32' choreographed by Louise Potiki Bryant as "dancing in the footsteps of the ancestors" (p. 283). The performances investigate mysterious, unknown and recuperated heritages that bear insights into their contemporary lives. Mazer notes "they bind their collective identity to the threads of their individual whakapapa (genealogy), and their choreography is often explicitly designed to evoke the past, to provide for the invocation of their ancestors through the medium of their dancing bodies" (p. 284). A founding member, past creative director and principal dancer, Dolina Wehipeihana states their creative process involves mapping landscapes with our 
histories; she says this is about discovering how our lineage "extends deep into the earth and continues into the future" (p. 285). Wehipeihana articulates the company's desire to use their performance research to create and strengthen environmental orientations and gauge the interrelatedness of biology, geography, culture and dance. Synthesizing these relationships is important to the collective and individual identities of Atamira Dance Company. The sentiments of the Māori land march are alive and put into action through the kaupapa Māori research and performances such as Taonga.

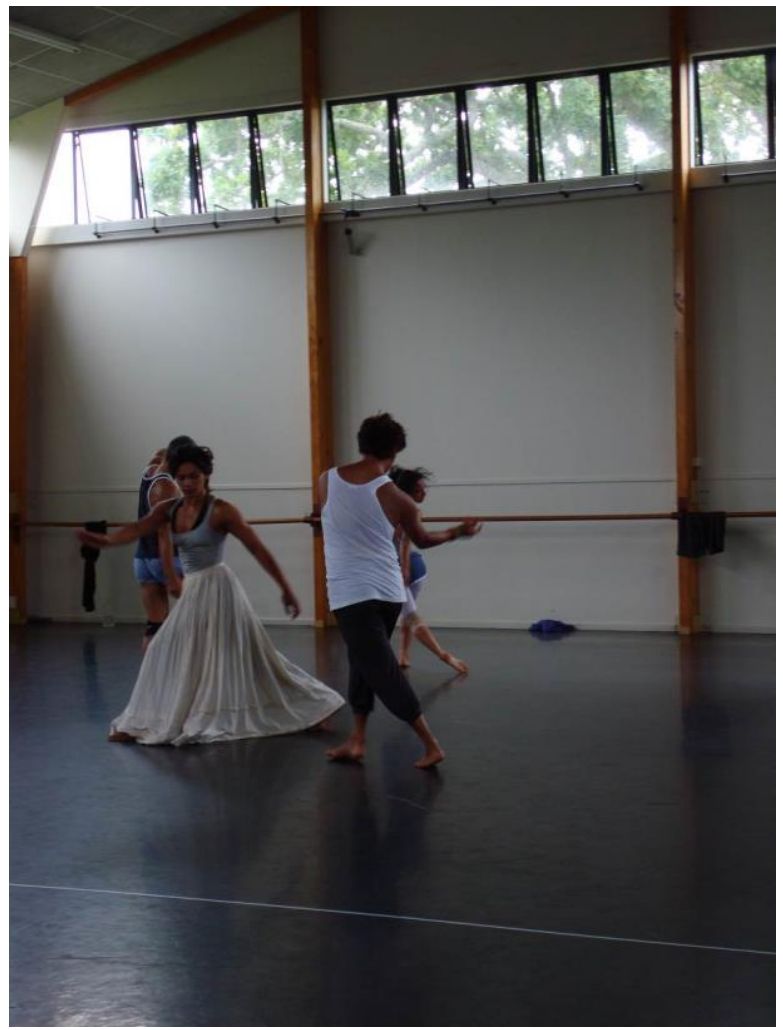

Photo: Ojeya Cruz Banks

Atamira Dance Company rehearsal at Unitec, February 2009 


\section{Kaupapa Māori Dance: Whakapapa in Action}

Moss Patterson, the current artistic director and choreographer for the company articulated a kaupapa/purpose for Māori dance as practiced by Atamira in which he said, we want to affirm a political consciousness about who we are as Māori in this contemporary world; it's about asserting the values and philosophies of Māoridom. We want this to be normal to the wider New Zealand society (personal communication, February 7, 2009). The company functions as a platform for invigorating, embodying and actualizing philosophies of kaitiakitanga, whakapapa and mana whenua. For example, Potiki Bryant describes Taonga in the 2009 performance program, "Bodies inhabit a world of seaweed, dust, feathers, water, wind and stone. A fantail echoes death, the moon and Rona-whakamautai guide the young girl, her Aunt and the wider whanau through the struggles and phases of their life. With bush clad hills to its back and the Southern Pacific Ocean spread out in front, Kaka point is a magical place". The dance increases Māori consciousness within the company and audiences by tuning into ancestral stories and ecological understandings of life.

For instance, Taonga works with the mythology of Ronawhakamautai/ Rona and the Moon, controller of the tides and feminine cycles; "I pair my Aunty's life with the mythological story of Ronawhakamautai, say Potiki Bryant (2009). The paragon, Ronawhakamautai resonated with Rona Williamson's life because she lived her whole life by the sea and remembers going to the moonlit water at nightfall with a calabash to harvest kelp with her mother. The memories Rona shared with her niece Potiki Bryant reminded Rona of her mother's intuition, and how she read the land and animals as signs. Ronawhakamautai represents the dark and bright phases on the moon; she guides ocean tides. Rona learned to 
read the tidal currents; this is necessary for locating kelp as seaweed grows fast in rough cold waters.

As part of the creative development of the piece, Potiki Bryant spent time in Kaka point and later arranged a visit for the company to take in the smells, to see the ocean, to meet the family, to feel the strong southerly winds, and to imagine what it must have been like to grow up in the area. The creative process leading up to performance was Potiki Bryant's visit with her family and the company's fieldwork. The company's dance research involves diligent observations of the subtle elements of the Kaka point landscape. The performance illuminates how their movement research kinetically conceptualizes the environmental scope and details of Kaka point/Catlins. In my (2011) description of Atamira Dance Company's work Taonga, "dancers move across the stage in flux, embodying hybrids of human(s) and birds, ghosts, angels, twilight and mythological characters. . . moving as if the ocean resided in their pelvises, their bodies are simultaneously heavy, light, fluid; they flick and ripple" (p. 80). The qualities of land, sea, birds, the southerly winds, and moon phases shaped the choreographic decisions made.

The performance echoes the worldview Kaitiakitanga and Moko Mead (1992) says this is tikanga/correct practice for Māori artistic endeavors. He declares pūmanawa, creative vision or talent should ultimately lead you back to Ranginui, Sky God and Papatuanuku, Mother Earth. He conceptualizes art as something that deepens your connection to whakapapa/ genealogy and a sense of mana whenua/ land empowerment.

Taonga: Dust, Water, Wind is oral history danced; and portrays the interrelatedness of people, sea, marine plants, the moon, trees, birds and so on.

The dancers reenact Kuia Rona Williamson's memoirs and the orientation to life passed on to her by her elders. As a child, her Mum taught her to pay attention to the messages of the fantails, the moon and to enjoy long gazes into the royal blue night sky. Through the company's investigation of Potiki 
Bryant whakapapa, Moss Patterson notes that a window into Māori past, present and future is revealed and the piece enables a collective story about our people can be told (informal conversation, Febuary 2009). Taonga and other works by Atamira actualize Māoritanga/Māori knowledge and the kaupapa/idea that the land and the people are one. Dance anchors the company to their ancestry and the spiritual places to which they belong; their performances fertilize Te Ao Māori worldviews.

Dance is a vehicle for Atamira to recover stories and worldviews that grant them insights into their heritage and indigeneity. This agenda helps to reconcile the psychological and spiritual consequences of the postcolonial circumstances. The dance work provides them with opportunities to investigate and live in Te Ao Māori worlds; however, the performances are not without contradictions, not untouched by colonial entanglements, intercultural meanings and clashes. In Mazer's (2007) analysis of Atamira's work, she calls this dilemma a postcolonial conundrum- this has to do with bicultural tensions and cultural hybridities reflective of the nation of New Zealand. She argues the piece Ngai Tahu 32 by Potiki Bryant makes visible and reveals "the breaks in histories rather than the continuities: the distance from land to city, the difference between the marae and the theatre and the desired glimpse of the ancestor and the realities faced by . .. descendants (p. 292)". Mazer describes the uneasy colonial induced conclusions that can be made by Māori and Pākeha spectators of Māori performances (2007, 2011, 2013).

For example Gwynne (2010), who reviewed Taonga, said the "piece gets me thinking about cultural romanticism and exoticism, and the ways in which Te Ao Māori is portrayed to a wider audience". Kaupapa Māori dance within a proscenium stage context can be seen as problematic because it embeds Māoritanga/ Māori knowledge in a Western frame that can provoke as Mcgwen expresses, illusive and touristic experiences and performances of culture. Another viewpoint 
to consider is the way the theatre can be reconceptualized and acculturated to be more in line with a Māori perspective (see McCallum, 2009). One illustration of this is how Potiki Bryant often replicates aspects of marae/ Māori ceremonial house structure and uses video design to involve images of the land on stage to invoke Māori ecological relationships or what Williams (2001) calls a kin-centric worldview. This describes humans and nature as "related parts to a unified whole ( $\mathrm{p}$. 31)". That being said, in a black box values of kaitiakitanga and whakapapa are out of context. It is not the whare tapere or the marae. Their performances reveal what Salmond (2013) calls ontological quarrels between Māori and Pāheka worldviews and show the affect of colonialism, commercialism, and cultural change. However another reviewer, Barbour (2011) notes their theme of celebrating whakapapa is reflected in a number of the company's choreographic works; she wrote, "they fulfil their kaupapa as they assert their unique voices as Māori artists and share their important stories".

In Royal's (2012) manifesto for indigenous development, he states, it is not motivated by postcolonial loss but rather focusing on what we have. Cultivating a new Māori Indigenous consciousness is about positive change and developing a creative potential that renews mana or an "active and dynamic spiritual presence and authority alive in the world" (Royal, p. 6). The challenges toward activating mana are complex and should not be dismissed but Royal encourages Māori communities such as the Atamira Dance Company to continue to imagine new possibilities and to view Māori knowledge as 'net national opportunity (p. 3)" for the country, not in a commercial sense but for cultural transformation, social justice and future possibilities. For over fifteen years now, the company has a history and repertoire of dance work nurturing "ethical principles and . . . cultural vitality" (Cruz Banks, 2010, p. 19) that promote kaitaikitanga, Māori pan-iwi solidarity, well- being and the understanding that their bodies are extensions of the rest of life around them. 


\section{Reclaiming Mana Whenua and Final Remarks}

The snapshot of Atamira Dance Company shows the importance of landscape as a primary source of creative consciousness and inspiration for developing knowledge that grows out of their respective lands. Strengthening ancestral ties bolsters relationships to the natural world and $\mathrm{Te}$ Ao Māori worldviews; and Orr (2004) says human intelligence evolves under these conditions; and more importantly diverse ecosystems or "elemental things such as flowing water, wind, trees, clouds, rain, mist, mountains, animal behavior, changing seasons, the night sky ... give birth to thought and language" (p. 52) and dance. There are many examples of indigenous people employing dance for reconceptualizing their identities that reach before and beyond colonial, European encounters and capitalism (Cruz Banks 2009; Flores 1996, 1999, 2004; Royal 2009; Teaiwa 2005, 2008; Moulin 2011)

I argue the cultural, political and performance work done by the Atamira Dance Company is a response to environmental imperialism. For instance, Tiffin (2007) points out that the very nature of colonialism is often characterized by land hijacking and space commodification. She says environmental racism leads to value shifts, and disconnection between human beings and their ecosystems; and the consequences of this reality are pressing, for the environment is a major constituent of identity. The on-going effects of Western imperialism and capitalism on environment and people signals how colonial enterprises and land dispossession can impoverish our cultural and biological definitions of humanity (see Tiffin, 2007; Gilbert 2007).

The predicament could be seen as glum. However, this research on the Atamira Dance Company demonstrates a move beyond colonial opposition, anger, compliance or cynicism towards land loss. Instead the company focuses on rebuilding a fluid relationship between land and identity. The dancers engage in decolonizing performances, "practices that 
represent and make indigenous life visible (Denzin, Lincoln and Smith (2011, p. 22)" Their political postures are attentive to needs of their whānau/family, wider Māori communities, reestablishing landscape bonds and hence their own spiritual well-being in order to facilitate knowledge creation that helps them 'navigate the future' (Durie, 2011). For example, a recent 'think piece' by Potiki Bryant (no date) articulates some challenges and opportunities for Māori dance. She encouraged the national funding body, Creative New Zealand to acknowledge that within a "Maori framework / world view a -'quality product' is seen to not only include the quality of the dance performed on the stage, but also the quality of our relationships with one another, our relationships with our environment, with our families and with our ancestors." Decisions about investing in Māori companies needs to be examined holistically, and when this happens Potiki Bryant goes on to say, "I believe in turn leads to a better and healthier 'quality' of dance on stage." Her advocacy highlights what she and other founding members of the Atamira Dance Company cherish, and that is the evolution of Māori knowledge or what Tama Huata calls (2010), "the shimmering pathways" of Māori identities and possibilities.

The Atamira Dance Company performance research demonstrates sensuous engagement with their lands that educates the dancers physically and spiritually. They dig out dormant genealogies and cosmologies that yield heritage and wisdom. What I have witnessed in the company is an ecological approach to knowledge construction through dance that is carried out with tenderness, and a curiosity of selfdiscovery. As the proverb says, Whāia ngā pae o te märamatanga me te aroha / Pursue the horizons of understanding and love. Their dancing enables them to calibrate Te Ao Māori literacies and worldviews that support mana whenua. As Hau'ofa states, ecological heritages formulate the very philosophies of Pacific societies (2000; 2008). The company's dance practices display a land ethics, 
one that reveres the environment with attention, carefulness, and respect.

The portrait of the company brings to light the intertwined destiny of cultural revitalization and environmental sustainability. In other words, indigenous ecological worldviews strengthen biophilia and secure environmental esteem. Atamira Dance Company demonstrates the way dance is ecologically constituted, and a source of kinetic story-telling, commemorations, and lineages; and how dance is an essential practice to the making of empowered Māori worlds. 


\section{Works Cited}

Barbour, K. (2011) Ngai Tahu 32- A Cohesive Overall Aesthetic. Retrieved from http: / / www.theatreview.org.nz/reviews / review.php?id=4326

Bradshaw, S. (2015). Contemporary Dance: A Māori Perpective. Dance Research Aotearoa 3(1), 76-94. 2015.

Cruz Banks, O. (2009) Critical Postcolonial Dance Recovery: An International Literature Review". Journal of Pedagogy, Society and Culture 17(3) 355-367.

---- (2010) .Of water and spirit: Locating dance epistemologies in Aotearoa/New Zealand and Senegal. Anthropological Notebooks 16 (3), 9-22.

_.( Dec. 2011) “Dancing Te Moana: Interdisciplinarity in Oceania”. Brolga 35, 85-83

---(2013) Espritu tasi/The ocean within: Critical dance revitalization in the Pacific. Dance Research Aotearoa 1(1), 24-36.

Denzin, N. K., Lincoln, Y. S., \& Smith, L. T. (Eds.). (2008). Part I Locating the Field: Performing Theories of Decolonizing Inquiry. In Handbook of critical and indigenous methodologies. Thousand Oaks, CA: Sage.

Dunham, K. (1947). Dances of Haiti. Acta Anthropologica 2(4):1-64, 1947.

---(2005). An Anthropological Approach to Dance. In Kaiso!:Writings

By and About Katherine Dunham. Veve A.Clark and Sara E. Johnson, eds. (p. 508-513). Madison: The University of Wisconsin.

Durie, M (2011). Ngā Tini Whetū: Navigating Māori Futures. Wellington: Huia Publishers

Gwynne, C. (2010). From Family Dinner to Cultural Romanticism and Exoticism. $\quad$ Retreived from http: / / www.theatreview.org.nz/reviews / review.php?id=2008.

Gray, J (2014) . Retrieved from https: / / www.youtube.com/watch?v=1CRNyd-4qMs.

Gray, J. Being Kaitiaki: A response to contemporary dance- a Māori perspective. Dance Research Aotearoa 3(1), 95-102. 2015.

Griffin, H. (2007). Ecotourism: A Colonial Legacy. In Five Emus to the King of Siam: Environment and Empire. Ed. Helen Tiffin. (p51-70) Rodopi: Amsterdam and New York.

Flores, J (1996). Reinventing Artistic Traditions: The Chamorro Search for Identity. Masters Thesis. University of Guam, Hagatna. 
_.(1999) Art and Identity in the Mariana Islands: Issues of reconstructing an ancient past. Phd. Norfolk: University of East Anglica.

- (2004) Artists and Activists in Cultural Identity Construction in the Mariana Islands. Shifting images of identity in the Pacific. Ed.s Toon van Meijl and Jelle Miedema Leiden: KITLV Press,

Hau'ofa, E. (2000). Epilogue: Pasts to Remember. Remembrance of Pacific Pasts: An Invitation to Remake History. Ed. Robert Borofsky. (p. 453-471) Manoa: University of Hawaii Press.

_.(2008) We are the Ocean. Honolulu: University of Hawaii. 2008

Huata, T. (2010). Acceptance speech for Lifetime Achievement Award in Māori Contemporary Dance at Kowhiti Premiere Programme Performance (June). Wellington, New Zealand. 2010

Kaeppler, A. (1978) Dance in Anthropological Perspective. Annual Review of Anthropology 7, 31-49.

---(2002) Dance Ethnology and the Anthropology of Dance. Dance Research Journal 32 (1):116-125.

Kawharu, M (2000) Kaitaikitanga: A Māori Anthropological Perspective of Māori Socio-Environmental Ethic of Resource Management. The Journal of Polynesian Society. 109 (4), pp. 349-370

Marae Television program. Māori Contemporary Dance Goes Global. Retrieved from https:/ / www.youtube.com/watch?v=X1RChRzhA0M

Mazer, S. (2007). "Atamira Dance Collective: Dancing in the Footsteps of the Ancestors". Performing Aotearoa: New Zealand Theatre and Drama in an Age of Transition. Ed. Marc Maufort and David O’Donnell,. Germany: P.I.E. Peter Lang. 2007. 283-292

---(2011) Performing Māori: Kapa Haka on the stage and on the ground. Popular Entertainment Studies 2 (1), 41-53.

---(2013). Skirting burlesque. Australasian Drama Studies 63 (2013): 24.

McCallum, R. (2009) "Rarotimu: Revisiting an indigenous mythology." Retrieved from http://review.mai.ac.nz/index.php/MR/article/viewFile/214/218

Moko Mead, H.(2003). Tikanga Māori: Living by Māori Values. Wellington: Huia Publishers. 2003

Moulin, J. F (2011) “The Dancer's Voice”. Presentation at Society of Ethnomusicology and Congress on Research in Dance Joint Annual Meeting. 18 November 2011

Orr, D. (2004). Earth in Mind. Washington: Island Press. 
Potiki Bryant, L. (2009) Interview on Radio New Zealand (March 9, 2009). Retrieved from

http://www.radionz.co.nz/concert/programmes/upbeat/audio/1 886705/louise-potiki-bryantived

---(no date) Retrieved from http://www.creativenz.govt.nz/assets/ckeditor/attachments/815 /lousie_ntm_dance.pdf?1377553743

Rae, B. (2009) Poems inspired by Kuia. Retrieved from http://www.theatreview.org.nz/reviews/review.php?id=2011

Royal, C. (2007) Ōrotokare: Towards of Model of Indigenous Theatre and Performing Arts. Performing Aotearoa: New Zealand Theatre and Drama in an Age of Transition. Ed. Marc Maufort and David O’Donnell (p 193-208) . Germany: P.I.E. Peter Lang

---. (2009a) Let the World Speak: Towards Indigenous Epistemology. Te Kaimānga: Towards a New Vision for Mātauanga Mãori.

_. (2009b) Te Whare Tapere: Ōrotokare”. Lecture at Aitanga: Māori Contemporary Dance Summit. 17 Oct.

_. (2010) Whakaahua - An Approach to Performance. Keynote address presentation at Dancing across the Disciplines: Cross Currents of Dance Research and Performance Throughout the Global Symposium (June 29). Dunedin, New Zealand.

--- (2012) Towards a Manifesto for Indigenous Development. Keynote at the International Development Research Conference, University of Auckland, New Zealand 27-30 June. Hosted by the Nga Pae o te Marmatanga.

Sciascia, P. (2013). Kapa haka's rich and developing cultural fabric. Dance Aotearoa New Zealand Magazine 20 th Anniversary Edition. p. 26-27.

Smith, H. (2011). E Tū Ake: Mãori Standing Strong. Wellington: Te Papa Press. 2011.

Teaiwa, K. (2005) Dances of Life. Retrieved from http://www.piccom.org/home/dancesoflife/oceania.html.

_. (2008). Saltwater Feet: The Flow of Dance in Oceania. Deep Blue: Critical Reflections on Nature, Religion and Water. Ed. Sylvie Shaw and Andrew Francis (p. 107-126) . London: Equinox.

TIffin, H. (2007) "An Introduction". Five Emus to the King of Siam: Environment and Empire. Ed. Helen Tiffin. (p. xi-xxxviii) Rodopi: Amsterdam and New York,

Williams, D. (2001). Matautanga Mãori and Taonga. Waitangi Tribunal Publication. 
Zaitz, C. (2009). "Matters of Life and Death: A Comparative Analysis of Content in Maori Traditional and Contemporary Art and Dance as a Reflection of Fundamental Maori Cultural Issues and the Formation and Perpetuation of Maori and Non-Maori Cultural Identity in New Zealand." PhD diss., Florida Atlantic University Boca Raton, Florida 